\title{
PENYELIDIKAN GEOMAGNET BIJIH BESI DI WILAYAH JORONG KOTA BIRAH, KECAMATAN SUNGAI PAGU KABUPATEN SOLOK SELATAN
}

\author{
Ceni Febi Kurnia Sari ${ }^{1}$ \\ Yoszi Mingsi Anaperta²
}

\begin{abstract}
The measureable magnetic field intensity variation is then interpreted in the form of the distribution of the magnetic material below the surface, then used as the basis for the prediction of possible geological conditions observed. The iron ore deposits in the survei area are generally interpreted as a form of sediment that fills the rock cavities, especially in limestone cavities. This occurs due to the geological structure that gives space for the placement of mineralization of ore deposits in the side rock zone. The value of this magnetic anomaly is located in the west, the eastern, and also in the north part.
\end{abstract}

Keywords: Geomagnet Method, Iron Ore, Magnetic Properties, Magnetic Value, Magnetic Anomaly Value.

\section{INTISARI}

Variasi intensitas medan magnetik yang terukur ditafsirkan dalam bentuk distribusi bahan magnetik dibawah permukaan, kemudian dijadikan dasar bagi pendugaan keadaan geologi yang mungkin teramati. Endapan bijih besi pada daerah survei ditafsirkan secara umum merupakan bentuk endapan yang mengisi rongga batuan terutama pada rongga batugamping. Hal ini terjadi akibat adanya proses struktur geologi yang memberi ruang terjadinya penempatan mineralisasi endapan bijih pada zona batuan samping. Nilai anomali magnetik ini terdapat pada bagian barat, bagian timur, serta pada pada bagian utara

Kata Kunci: Metode Geomagnet, Bijih Besi, Sifat Magnetik, Nilai Magnetik, Nilai Anomali Magnetik

\footnotetext{
${ }^{1}$ Dosen Universitas Papua

${ }^{2}$ Dosen Fakultas Teknik Universitas Negeri Padang
} 


\section{PENDAHULUAN}

Dalam pemanfaatan potensi sumberdaya mineral logam diperlukan tahapan eksplorasi yang benar dan tepat sehingga diperoleh data-data yang valid untuk mengurangi resiko dalam kegiatan penambangannya. Penambangan bijih besi sangat dipengaruhi oleh banyak aspek, salah satunya mengetahui aspek potensi bahan galian tersebut dengan melakukan survei geologi, geofisika dan pemboran sehiingga diperoleh data sebaran zona prospek endapan bijih besi, jumlah dan kualitasnya. Hal ini sangat penting dalam pertimbangan ekonomis atau tidaknya bahan galian tersebut untuk ditambang serta membantu dalam perencanaan penambangannya. Dalam eksplorasi endapan bijih besi, metoda geofisika yang sering digunakan yaitu geomagnet, geolistrik, dan Induced Polarization (IP).

Metode geomagnet didasarkan pada pengukuran variasi intensitas medan magnetik di permukaan bumi yang disebabkan oleh adanya variasi distribusi benda termagnetisasi di bawah permukaan bum, sedangkan metoda geolistrik 2D dan IP merupakan 2 metoda geofisika yang dapat merespon sifat kelistrikan batuan di bawah permukaan, yaitu resistivitas dan chargeability. Apabila dari hasil pengukuran metoda geolistrik tidak ditemukan anomali resistivitas, maka digunakan metoda IP. Menurut Telford (1990) dalam eksplorasi logam dasar seperti bijih besi umumnya dilakukan penggabungan 2 metode geofisika yaitu metode resistivitas dan IP. Tujuan survei metoda geomagnet dan geolistrik adalah untuk mengidentifikasi penyebaran lateral dan vertikal tubuh bijih besi di bawah permukaan berdasarkan parameter fisika batuan (karakteristik kemagnetan dan kelistrikannya) di bawah permukaan bumi.

Daerah survei yang termasuk kedalam wilayah Jorong Kota Birah, Kecamatan Sungai Pagu, Kabupaten Solok Selatan, Propinsi Sumatera Barat, dengan luas area sekitar $\pm 25 \mathrm{Ha}$. Peta lokasi survei penelitian dapat dilihat pada gambar 1 di bawah ini.

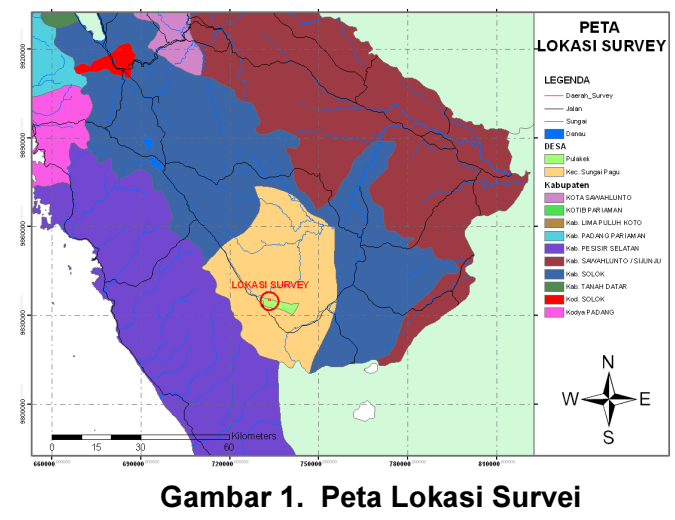

\section{PENDEKATAN PEMECAHAN MASALAH \\ Prinsip Dasar Metode Geomagnet Hukum Coulomb} Jika ada dua buah kutub magnetik $m_{1}$ dan $m_{2}$ yang berjarak $r$, maka gaya yang ditimbulkannya adalah :

$F=k \frac{m_{1} m_{2}}{r^{3}} r$ dyne

dimana : $k=\frac{1}{4 \pi \varepsilon_{0}}=8.85 \cdot 10^{-12}$ farad $\mathrm{m}^{-1}$. Jika muatan yang berinteraksi lebih dari dua buah, gaya magnetik totalnya adalah :

$F=\frac{q_{0}}{4 \pi \varepsilon_{0}} \sum_{i=1}^{n} \frac{q_{i}}{r_{i}^{3}} r$

\section{Kuat Medan Magnetik}

Pada titik yang berjarak $r$ dari kufub $m$, kuat medan magnetik pada titik tersebut didefinisikan sebagai : 


$$
H=\frac{R(r)}{m}
$$

Tetapi di alam kutub-kutub magnet berpasangan (dipol), kerapatan fluks:

$$
B=\mu H
$$

Dengan $\mu=$ permeabilitas absolut $=$ $\mu_{\mathrm{r}} \mu_{0}$. Dalam vakum $\mathrm{B}_{0}=\mu_{0} \mathrm{H}$ maka persamaan tersebut menjadi :

$$
B=\mu_{r} \mu_{0} H
$$

\section{Intensitas Magnetisasi}

Suatu benda magnetik yang ditempatkan pada suatau medan magnet akan mengalami magnetisasi oleh imbas medan magnetik yang didefinisikan sebagai :

$$
I=\frac{M}{V}
$$

dimana :

$$
\begin{aligned}
\mathrm{M}= & \text { momen magnetik dwikutub } \\
& (\text { dipol })=\mathrm{mlr} \\
\mathrm{I} & =\text { jarak antara kutub }+\mathrm{m} \text { dan } \\
& -\mathrm{m} \\
\mathrm{V} & =\text { volume benda }
\end{aligned}
$$

I disebut juga polarisasi magnetik. Derajat magnetisasi dalam daerah isotropik adalah $\mathrm{I}=\mathrm{kH}, \mathrm{k}$ adalah suseptibilitas maka dapat dikatakan, apabila suatu benda magnetik kita letakkan dalam suatu medan magnet luar $\mathrm{H}$ maka kutubkutub internalnya akan menyearah dan membentuk suatu medan induksi (imbas) $\mathrm{H}^{\prime}$ :

$$
\begin{aligned}
& B=H+H^{r}=\mathrm{H}+4 \pi \mathrm{I}=(1+4 \pi K) H \\
& \quad= \\
& \quad \text { HH gauss }(\mathrm{cgs})
\end{aligned}
$$

\section{Intensitas Medan Teramati}

Intensitas medan magnet di permukaan bumi diukur menggunakan magnetometer. Hasil pengukuran magnetometer berupa penjumlahan dari medan magnet bumi utama, variasi medan magnet bumi yang berhubungan dengan variasi kerentanan magnet batuan, medan magnet permanen dan variasi harian akibat aktivitas matahari. Pada pengamatä intensitas medan magnet bumi, harga yang teramati $\mathrm{H}$ terdiri dari :

$H_{p}=H_{0}+\Delta D+\Delta T$

Dimana :

$\mathrm{H}_{0}=$ medan magnet bumi rata-ratla di titik pengamatan

$\Delta \mathrm{D}=$ medan magnet gangguan dari luar bumi,

$\Delta \mathrm{T}=$ medan anomali.

\section{Sifat Anomali Medan Magnet}

Berdasarkan sifat medan magnet bumi dan sifat kemagnetan bahan pembentuk batuan, maka bentuk medan magnetik anomali yang ditimbulkan oleh benda penyebabnya tergantung pada inklinasi medan magnet bumi di sekitar benda penyebab, geometri benda penyebab, kecenderungan arah dipol-dipol magnet di dalam benda penyebab, dan orientasi arah dipol-dipol magnet-benda penyebab terhadap arah medan bumi.

\section{METODE}

Metoda Pengukuran Geomagnet

Sebelum akuisisi data di lapangan, dilakukan terlebih dahulu langkah-langkah persiapan. Persiapan didahului oleh penentuan koordinat lokasi penelitian menggunakan GPS (Global Positioning System). Langkah selanjutnya adalah pembuatan lintasan geomagnet. Secara umum lintasan geomagnet dibuat mengikuti garis lurus dengan arah barat-timur dan utara-selatan. Akuisisi data dibagi mejadi dua yaitu akuisisi data intensitas medan magnet bumi diurnal (harian) dengan menggunakan stasiun base (stasiun A) dan akuisisi data anomali medan 
magnet penyusun kerak bumi dengan stasiun mobile (stasiun B). Pencatat waktu (time) kedua stasiun tersebut telah disamakan. Pengambilan data magnetik dilakukan dengan spasi yang serapat mungkin agar data yang diperoleh banyak. Pengambilan data juga harus disesuaikan dengan topografi dan keadaan vegetasi lokasi survei. Untuk daerah yang sulit dijangkau, spasi pengambilan data dapat divariasikan.

\section{Pengolahan Data Dan Interpretasi \\ Data intensitas medan} magnet yang diukur dengan stasiun A digunakan untuk mengoreksi nilai intensitas medan magnet pada stasiun B. Koreksi data dilakukan secara sederhana yaitu menghitung selisih antara nilai-nilai pada kedua stasiun pada waktu yang sama. Selain itu perlu diperhatikan datadata yang ekstrim. Data ekstrim ini pada umumnya disebabkan oleh aktivitas matahari. Jika pada stasiun base tidak terukur nilai-nilai ekstrim, maka kemungkinan besar di daerah tersebut terdapat cebakan magnetik. Nilai ekstrim bisa mencapai 100.000 nT. Medan magnet gangguan dari luar bumi atau variasi harian (diurnal) secara dominan disebabkan oleh gangguan matahari. Radiasi ultraviolet matahari menimbulkan ionisasi lapisan ionosfer. Adanya ionisasi ini dan juga adanya elektron-elektron yang terlempar dari matahari akan menimbulkan fluktuasi arus sebagai sumber medan magnet. Sifat perubahan harian ini acak tetapi periodik dengan perioda rata-rata sekitar panjang hari matahari (24 jam). Untuk menghilangkan variasi harian medan magnet perlu dilakukan koreksi dengan mengukur medan magnet secara tetap di base station dalam jangka waktu tertentu. Dari hasil pengukuran medan magnet di base station, dibuat grafik intensitas medan magnet terhadap waktu . Dengan menarik garis sejajar sumbu waktu sebagai harga acuan basis melewati titik pertama, dapat dihitung harga penyimpangan grafik terhadap harga acuan basis untuk waktu-waktu yang bersesuaian dengan waktu-waktu pengukuran di statiun-stasiun. Untuk waktu-waktu yang bersesuaian, harga di stasiun dikoreksi dengan harga penyimpangan tersebut. Dari harga intensitas medan magnet teramati yang telah dikoreksi dengan koreksi harian (diurnal correction) maka dapat dihitung harga medan anomali $(\Delta \mathrm{H})$ sebagai berikut :

$\Delta H=H^{*}-H_{0}$

Dimana :

$\mathrm{H}^{*}=$ Intensitas magnet yang teramati setelah dikoreksi variasi harian.

$\mathrm{H}_{0}=$ Harga rata-rata intensitas medan magnet bumi di daerah survei

Dalam hal ini harga rata-rata intensitas medan magnet bumi digunakan adalah harga dari IGRF = International Geomagnetic Reference Field yang dapat dilihat pada Gambar 2.

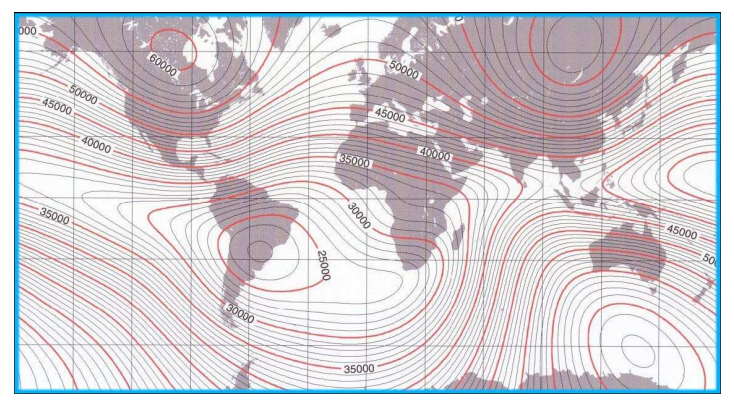

Gambar 2. Harga Rata-Rata Intensitas Medan Magnet Bumi (IGRF)

Dari harga anomali medan magnet tersebut kemudian dibuat peta kontur anomali magnetik yang siap ditafsirkan secara kualitatif dalam hal ini dengan prospek keberadaan endapan bijih besi. 
Adanya endapan bijih besi di bawah permukaan akan memperkuat medan magnet yang terukur di permukaan yang akan tergambarkan di dalam peta anomali magnetik berupa bentuk kontur melingkar tertutup dan mempunyai nilai anomali magnetik yang relatif lebih tinggi dari sekitarnya.

\section{Peralatan}

Peralatan yang digunakan untuk survei geomagnet adalah sebagai berikut :

- Global Positioning System (GPS)

- GEM System GSM 19 T Proton Magnetometer

- Sensor

- Kompas geologi

- Laptop

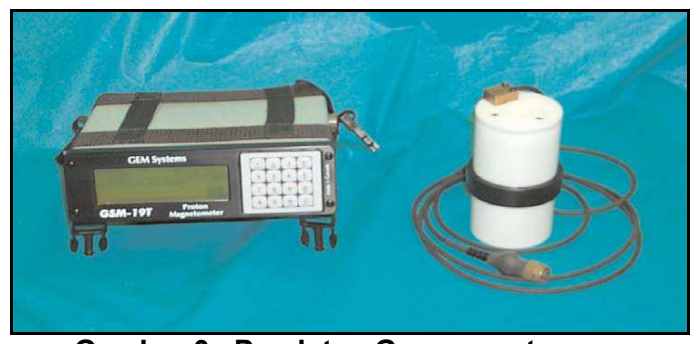

Gambar 3. Peralatan Geomagnet

\section{HASIL DAN PEMBAHASAN}

Morfologi dan Kondisi Lokasi Survei

\section{merupakan}

Morfologi daerah survei

bergelombang tinggi dengan

kemiringan lereng terjal hingga sangat terjal dan ketinggian berkisar 700 meter hingga 910 meter diatas permukaan laut. Morfologi ini terbentuk oleh batuan intrusi diorit, batugamping dan batuan ubahan. Daerah perbukitan di bagian selatan umumnya telah dimanfaatkan oleh penduduk setempat untuk kebun karet, sedangkan perbukitan dibagian utara masih ditutupi oleh vegetasi hutan dan semak belukar. Di beberapa tempat terdapat lahan terbuka yang telah diusahakan sebagai area penambangan bijih besi.

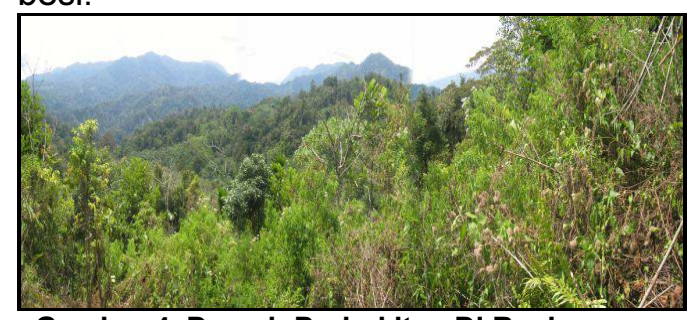

Gambar 4. Daerah Perbukitan Di Bagian Selatan Daerah Survei

Sungai yang terdapat di daerah survei merupakan cabang sungai kecil dengan lebar \pm 1 meter, lembah-lembahnya terjal, arah erosi dominan vertikal.

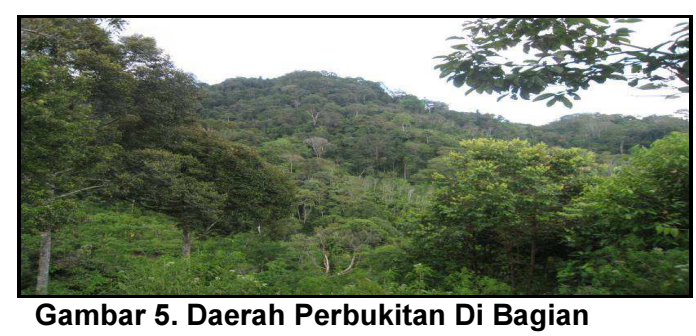
Utara Daerah Survei

\section{Geologi dan Potensi Bijih Besi Daerah Survei}

Daerah survei merupakan bagian dari Busur Magmatik Barisan yang tersusun oleh batuan metamorf dan batuan beku intrusif. Batuan yang tersingkap di daerah survei terdiri atas batuan beku dioritik, batugamping yang termetamorfkan dan batuan alterasi. Batugamping diperkirakan bagian dari Anggota Batugamping Formasi Barisan yang berumur Perm. Batuan beku dioritik menempati bagian selatan daerah survei. Singkapannya berwarna kelabu terang-kelabu gelap, agak kasar permukaannya (fanerik), keras, kompak, tampak kristal kuarsa, plagioklas dan mineral mika. Batugamping termetamorfkan menempati bagian utara daerah survei. batuannya termetamorfkan, berwarna biru-biru tua, keras, kompak, banyak retakan terisi silika dan kalsit. Batuan alterasi yang 
tersingkap berupa batuan silika dan argilit, termineralisasi sebagian, dimana pembentukan batuan tersebut diduga akibat pengaruh intrusi batuan dioritik. Sebaran batuan-batuan tersebut dapat dilihat pada Gambar 6 dan 7.

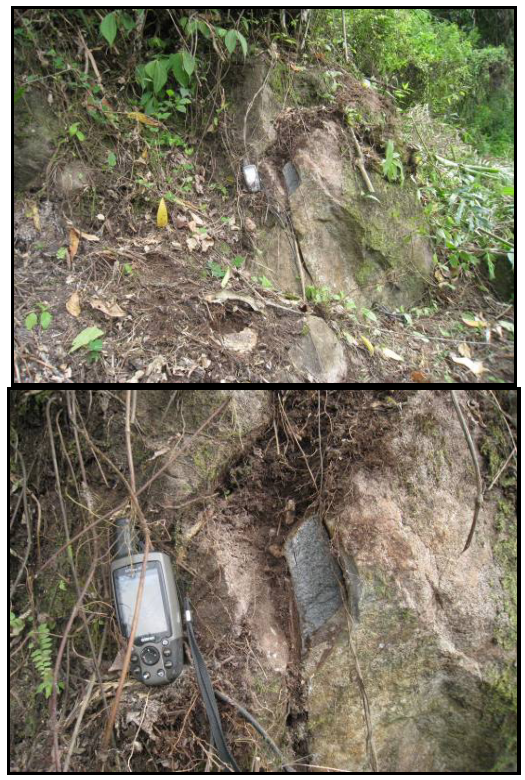

Gambar 6. Singkapan Batuan Beku Dioritik Di Bagian Selatan Daerah Survei

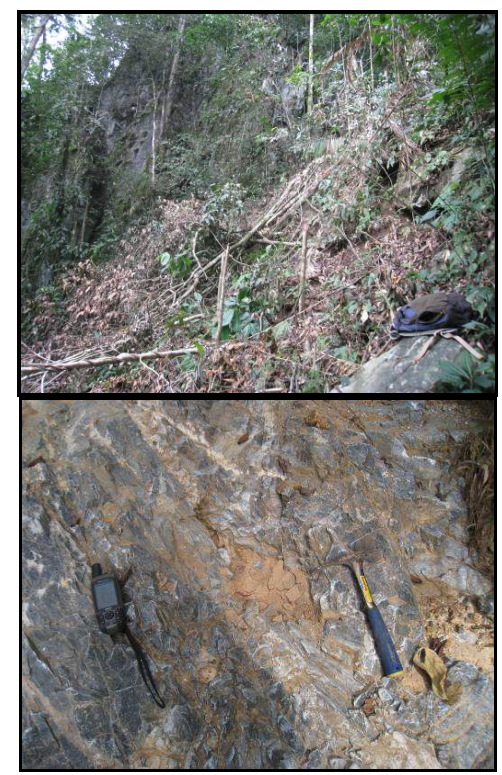

Gambar 7. Singkapan Batugamping Di Bagian Utara Daerah Survei
Daerah survei diperkirakan terletak pada zona patahan geser yang berorientasi baratlaut-tenggara dan utara-selatan. Patahan tersebut mengontrol zona mineralisasi di daerah survei.

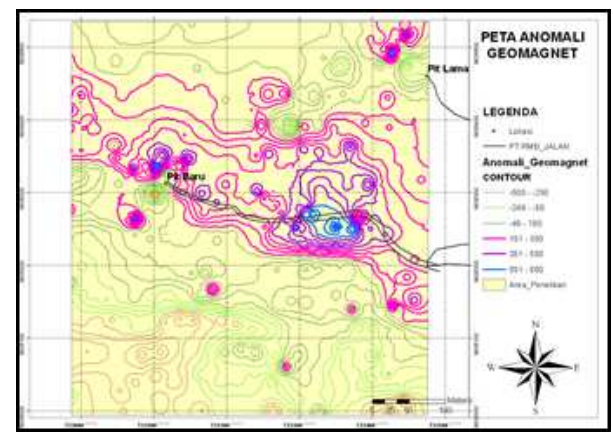

Gambar 8 Peta Anomali Magnetik Daerah Survei

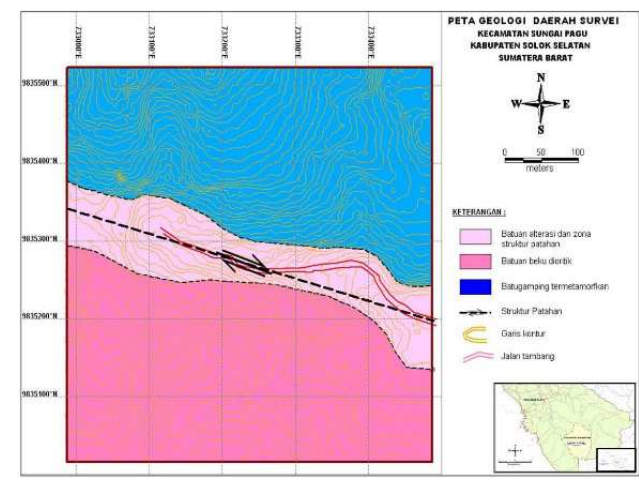

Gambar 9. Peta Geologi Daerah Survei

Daerah survei memiliki potensi endapan bijih besi yang didominasi oleh endapan jenis laterit dan tidak menutup kemungkinan terdapatnya endapan bijih besi primer yang berupa endapan bijih yang mengisi celah rekahan atau rongga pada batuan. Endapan laterit terdapat pada bagian top soil yang merupakan hasil pelapukan batuan dasar yang membawa atau tempat terjebaknya mineral-mineral bijih logam. Di daerah survei, batugamping dan batuan dioritik sebagai batuan dasar endapan laterit. Pada endapan tersebut terkandung fragmen bijih besi magnetit dan hematit, berukuran kerikil-bongkah, berbentuk sub- 
angular sampai angular. Di beberapa tempat terdapat bijih besi yang tercebak pada celah atau rongga batugamping. Pembentukan endapan bijih besi diduga sebagai hasil dari diferensiasi cairan sisa magma dioritik sebagai pembawa mineral-mineral ferromagnetik yang mengisi rongga pada batuan Formasi Barisan. Mineral logam lainnya yang terbentuk di daerah survei yaitu mangan dan malakit. Sebaran mineralisasi di daerah survei umumnya dikontrol oleh struktur geologi berupa patahan geser. Peta geologi daerah survei dapat dilihat pada gambar 8 .

\section{Interpretasi Survei Geomagnet} Survei geomagnet yang dilakukan pada daerah survei dimaksudkan untuk melakukan deliniasi area prospek endapan bijih besi. Proses deliniasi area prospek diindikasikan dengan adanya anomali magnetik yang terdapat dari hasil pengukuran sifat magnetik insitu yang terdapat pada area survei. Pengukuran sifat magnetik dilaksanakan dengan melakukan pengukuran pada titik-titik pengamatan yang berjarak $20 \mathrm{~m}$ $25 \mathrm{~m}$ pada lintasan pengukuran geomagnet dengan arah lintasan mengarah barat - timur sepanjang \pm $500 \mathrm{~m}$ dengan jumlah lintasan 22 lintasan pengukuran. Berdasarkan hasil pengukuran yang dilaksanakan, daerah penyelidikan memiliki beberapa lokasi dengan nilai magnetik yang relative lebih tinggi dari sekitarnya. Nilai magnetik ini dianalisa dan dikoreksi oleh nilai magnetik harian untuk kemudian dituangkan kedalam peta anomali magnetik.

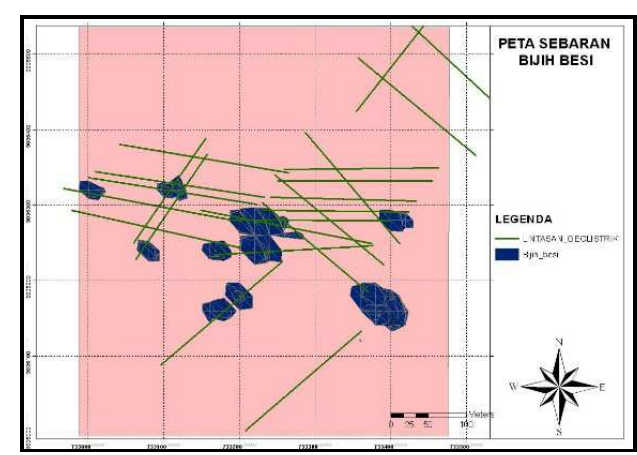

Gambar 10. Peta Sebaran Bijih Besi Hasil Interpretasi Geomagnet Di Daerah Survei.

Hasil pengukuran sifat magnetik insitu didapat adanya beberapa nilai magnetik dengan kisaran harga $350 \mathrm{nT}$ sampai dengan $850 \mathrm{nT}$ dengan puncak nilai magnetik ada pada kisaran harga 550 nT sampai dengan 850 nT. Berdasarkan hasil analisa peta anomali magnetik kisaran harga magnetik $350 \mathrm{nT}$ sampai dengan $850 \mathrm{nT}$ dapat menjadi indikasi terdapatnya endapan bijih besi. Nilai anomali magnetik ini terdapat pada bagian barat, bagian timur, serta pada pada bagian utara. Peta anomali magnetik daerah survei dapat dilihat pada gambar 9 .

Berdasarkan interpretasi tersebut endapan bijih terutama endapan bijih besi pada daerah survei ditafsirkan secara umum diduga merupakan bentuk endapan yang mengisi rongga batuan terutama pada rongga batugamping yang terbentuk akibat adanya proses struktur geologi yang memb--.... ang terjadinya penempatan mineralisasi endapan bijih pada zona batuan samping. Proses pembentukan endapan bijih yang seperti ini akan menyebabkan terbentuk endapan bijih yang berupa titik - titik endapan yang menyebar sepanjang daerah kontak struktur geologi dengan mengikuti pola rongga atau rekahan pada batuan seperti yang ditunjukan oleh hasil pengukuran geomagnet (gambar 9). Struktur geologi yang 
dimaksud adalah struktur geologi mendatar yang berkembang memotong hamper tepat di bagian tengah daerah survei. Daerah kontak ini diduga merupakan daerah ubahan yang digunakan untuk tempat terbentuknya endapan bijh, serta adanya dugaan dimana struktur geologi sesar mendatar dengan bentuk topografi yang agak curam menyebabkan terbentuknya tingkat pelapukan yang cukup kuat sehingga memungkinkan terbentuknya endapan bijih laterit. Peta Sebaran Bijih Besi hasil interpretasi Geomagnet di daerah survei dapat dilihat pada gambar 10 .

\section{KESIMPULAN}

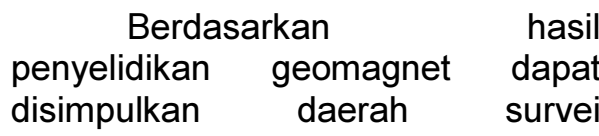
merupakan daerah dengan topografi perbukitan bergelombang dengan tingkat kemiringan lereng dari curam sampai agak curam yang terbentuk melalui kontrol struktur geologi. Morfologi secara umum ditumbuhi oleh pepohonan karet, vegetasi hutan serta belukar. Daerah survei secara umum terbentuk oleh 3 jenis batuan yang terdiri dari batuan diorite, batugamping serta batuan ubahan yang diduga terbentuk akibat adanya proses alterasi pembentukan endapan bijih. Batuanbatuan ini diperkirakan memiliki umur perm. Struktur geologi yang berkembang pada daerah survei merupakan bagian atau orde selanjutnya dari struktur geologi utama pada daerah sumatera yaitu sesar bukit barisan yang berupa sesar mendatar dekstral. Struktur geologi berarah barat laut tenggara yang menjadi kontrol pembentukan mineralisasi endapan bijih pada daerah survei. Berdasarkan hasil pengukuran gemagnet menunjukkan endapan bijih terendapkan secara setempat. Hal ini ditunjukan dengan adanya anomaly magnetik dengan kisaran harga $550 \quad \mathrm{nT}$ sampai $850 \mathrm{nT}$ Berdasarkan pengukuran geomagnet serta memperhatikan kondisi geologi berdasarkan pengamatan megaskopis, maka endapan bijih besi secara umum karakteristik endapan diduga merupakan endapan cavity filling dan endapan laterit.

\section{DAFTAR PUSTAKA}

[1] Bemmelen, R.W.V. 1949. The Geology of Indonesia. Government Printing Office.

[2] Burger, H. R., Sheehan, A. F., dan Jones, C. H. 1992. Introduction to Applied Geophysic Exploring the Shallow Subsurface. W.W. Norton \& Company. New York.

[3] Davis, A.E., \& Hartati, R.D. 1991. Procedures Manual for The Anayisis Of Geophisic Samples, Geological And Mineral Exploration Project. SSGMEP. Report Series No 6. Directorate Of Mineral Resources.

[4] Ghazali, S.A., Muchsin, A.M. 1996. Penyelidikan Geofisika Regional. Departemen Pertambangan dan Energi, Direktorat Sumber Daya Mineral Bandung, tidal dipublikasikan, laporan tahunan.

[5] Howart.,R.J. 1983. Handbook of Exploration Geochemistry, Vol.2. Elsevier. Statistical and Data Analysis In Geochemical Prospecting

[6] Hawkes and Webb. 1965. Geochemistry in Mineral Exploration Harper \& Row, New York, Evanston and London and John Weatherhill, Inc, Tokyo

[7] Telford W.M, Geldart, L.P. Sheriff, R.E. Keys, D. A. 1976. Aplied Geophysics. Second edition. Cambridge University Press. Cambridge. 
VOL. 10 NO. 3 Oktober 2017

[8] Untung, M. 2001. Dasar-dasar Magnet dan Gaya Berat Serta Beberapa Penerapannya. Himpunan Ahli Geofisika Indonesia.

[9] Rusman. 2010. Model-model Pembelajaran

Mengembangkan

Profesionalisme Guru. Jakarta: PT Rajagrafindo Persada.

[10] Trianto. 2009. Mendesain Model Pembelajaran InovatifProgresif. Jakarta: kencana Prenada media group. 